\title{
Badranaya: A Board Game to Enhance Prospective Multicultural Counselors' Impartial Character
}

\author{
(Badranaya: Board Game untuk Memperdalam Karakter Adil Calon Konselor Multibudaya)
}

\author{
Nora Yuniar Setyaputri*, Yuanita Dwi Krisphianti, Rosalia Dewi Nawantara \\ Department Guidance and Counseling, Faculty of Teacher Training and Education, Universitas Nusantara PGRI Kediri, \\ KH. Ahmad Dahlan St., Kediri, East Java, 64112 Indonesia \\ *corresponding author, e-mail: setyaputrinora@gmail.com
}

Article received: October $25^{\text {th }} 2020$; revised: December $30^{\text {th }} 2020$; accepted: January $11^{\text {th }} 2021$

\begin{abstract}
The discriminative behavior upon individual personalities that multicultural counselors have frequently operated causes low neutrality in encountering an issue and individual labeling. That behavior indicates the counselors lack impartial character. Thus, this study aims to develop a guidance and counseling media of Badranaya (multicultural counseling board game) that promote unbiased character, referring to Semar's great characters. It used modified Borg and Gall development procedures, while its data were obtained through valid and reliable experts assessment questionnaire and impartial character scale. The numerical data analysis results from guidance and counseling experts, as well as educational media development experts, signify that this media is highly feasible to be used. Meanwhile, the qualitative data from experts in the related fields also confirms the media's feasibility to be adopted as a new educational media breaktrough, primarily in prospective counselors' education. Additionally, the paired sample test results also show an increase in the multicultural counselors' impartial character after they play Badranaya.
\end{abstract}

Keywords: efficacy; Badranaya; prospective multicultural counselor; impartial character

\begin{abstract}
Abstrak: Perilaku membeda-bedakan kepribadian individu satu dengan yang lain, kurang netral ketika menghadapi suatu permasalahan, dan munculnya pelabelan pada individu lain yang dilakukan oleh para calon konselor multibudaya sering kali terjadi. Perilaku tersebut menandakan kurangnya karakter adil pada calon konselor multibudaya. Tujuan dari penelitian ini yaitu untuk mengembangkan media bimbingan dan konseling untuk memperdalam karakter adil yang mengacu pada nilai luhur Semar. Media yang dipilih adalah Badranaya (Board game Karakter Konselor Multibudaya). Metode penelitian yang digunakan adalah model pengembangan Borg dan Gall yang dimodifikasi. Data penelitian digali menggunakan Kuesioner Penilaian Ahli dan Skala Pengukuran Karakter Adil yang valid dan reliabel. Berdasarkan hasil analisis data numerikal ada ahli materi bimbingan dan konseling serta ahli pengembangan media pendidikan, media dikategorikan sangat layak digunakan. Setelah ditandingkan dengan diskusi hasil data verbal pada ahli-ahli terkait ditarik sebuah kesimpulan bahwa media ini layak digunakan sebagai salah satu terobosan media pendidikan baru khususnya pada pendidikan calon konselor. Berdasarkan hasil perhitungan paired sample test, dapat disimpulkan bahwa tingkat karakter adil calon konselor multibudaya naik setelah memainkan Badranaya.
\end{abstract}

Kata kunci: kemanjuran; Badranaya; calon konselor multibudaya; karakter adil 


\section{INTRODUCTION}

Multicultural competence is not just emerged from counselors, but it should be trained and habituated to them (Corey, 2013). It is closely associated with the ideal characters of the multicultural counselor. Those characters can be connected to one of the local culture characters to preserve the local wisdom. For instance, Indonesia's ideal character can adopt 12 excellent characters formulated from Semar's great characters (Setyaputri, 2017). Semar is one of Indonesia's great cultural characters who has been slowly abandoned. The characters selected from Semar involve religiosity, neutrality, tolerance, sincerity, discipline, social care, friendliness, fairness, honesty, flexibility, democratic, and curiosity (Setyaputri, 2017). Semar was selected due to his thorough characters for the living picturization (Setyaputri, 2017).

In relation to that characters, the discriminative behavior is observed among the undergraduate guidance and counseling students in Universitas Nusantara PGRI Kediri. It is shown from their biased attitude in responding to facing an issue and also their stereotyping behavior. As a prospective multicultural counselor, they should not stereotype people since counseling service gives no space for stereotypes and cultural myths (Geldard \& Geldard, 2005). Besides, the students have not entirely internalized the courses' values, and there has not been a special intervention carried out to minimalize those behaviors.

According to the definition of impartial character Semar's great characters, these phenomena are caused by prospective counselor's lack of impartial character. Future counselors are expected to master multicultural competence when they work in a school or other places. Thus, these phenomena bring great concern since that competence is an effort to realize excellent guidance and counseling service with cultural values. One of the efforts to enhance counselor's competencies is by promoting indigenous values, cultures, and customs (Alfadla \& Trisnawati, 2019). It aims to manifest indigenous personal in the multicultural counselor. Indigenous multicultural counselors place tradition as the primary component of culture. The indigenous term covers the elements of spirituality, emotional, mental, and physical elements of a being (Absolon, 2010). Those elements become a complete unit on an individual that remains to be acknowledged, forever. Individuals with those elements can accept and survive the changes of the era. Consequently, a guidance and counseling innovation media that enhances the prospective counselors' impartial character by internalizing Semar's great values is required. The use of media in a guidance and counseling service is highly suggested since it is an essential component in the service (Nursalim, 2013).

This study aims to develop a board game media that extends multicultural counselors' impartial character. The board game is a visual media that can be operated as a game (Prameswara \& Siswanto, 2016; Setyanugrah \& Setyadi, 2017) and used as a simulation tool and learning media (Elianta, Prestiliano, \& Setiawan, 2019). Additionally, it is proven to improve high school students' learning interest (Yunita \& Wirawan, 2017). A game was selected since people have a natural instinct to play a game as a refreshment, while it can also be a catharsis from their current problem. By playing games, an individual experiences an authentic emotion creates their private world, gains new experiences, responds to a new situation, adapts to various conditions, creates friendship, and learns to establish self-confidence and self-defense, self-reward, and self-determination (Gleave \& Cole-Hamilton, 2012). Therefore, a board game was selected as the media to increase the prospective multicultural counselors' impartial character. Besides, it can also be used to simulate the materials formulated to enhance impartial character, consisting of brainstorming, role play, and practicing to conceive new behavior. The board game was named Badranaya.

\section{METHOD}

This study used Borg and Gall's research and development procedure (Borg \& Gall, 1983). Form the ten Borg and Gall procedures, only six stages were carried out. First, a data-gathering involving an introduction study, literature study, and study on the developed counseling and guidance media was carried out. Second, planning that covered commentary on the skills required during the research. Third, the initial product development, which included the planning of prototype, instruments, and materials 
development. Fourth, the initial field tries out, where the media was consulted to an educational media expert and a guidance and counseling expert and tried out to six undergraduate guidance and counseling students of Universitas Nusantara PGRI Kediri. The last stage was the final product of Badranaya.

The instrument used to assess the developed product was an expert assessment questionnaire and impartial character scale. The questionnaire was developed based on the guidance and counseling media selection criteria, while the impartial character scale was formulated according to impartial character indicators based on Semar's great character. After the instrument outline was formulated, 20 items were explained from each indicator. The instrument validity test revealed 12 valid and eight invalid items with a reliability score of 0.834 . The test results indicate that the instrument was classified as accurate and reliable to be used to assess the impartial character of a prospective multicultural counselor (Setyaputri, Krisphianti, \& Nawantara, 2020).

The small group of subjects was purposively selected from the population. It was limited to six students with low and poor impartial character. The quantitative analysis results on data obtained from the experts' test determine the range of each criterion. Simultaneously, the percentage was decided using Formula 1 (Sudjana, 2011).

$$
\frac{\text { observation result score }}{\text { maximal score }} \times 100 \%
$$

The category used for expert assessment questionairre is presented in Table 1, while the criteria used to interpret pretest and posttest are shown in Table 2. The qualitative data obtained from experts' and small try out subjects' suggestion was analyzed by drawing conclusions from their explanation. The hypothesis was tested using Paired T-Test Sample using SPSS IBM Statistic 20.0. If the significance is less than 0.5 , then the null hypothesis is rejected, but if the significance score is more than 0.05 , then the null hypothesis is accepted. The null hypothesis was no difference of prospective multicultural counselors' impartial character before and after playing Badranaya. Meanwhile, the alternative hypothesis was a difference of impartial character from future multicultural counselors before and after playing Badranaya.

Table 1. Expert Assessment Category

\begin{tabular}{ccc}
\hline No. & Range & Category \\
\hline 1. & $0 \%-25 \%$ & Not feasible \\
2. & $26 \%-50 \%$ & Less feasible \\
3. & $51 \%-75 \%$ & Feasible \\
4. & $76 \%-100 \%$ & Highly feasible \\
\hline
\end{tabular}

Table 2. Criteria Used to Interpret Pretest and Posttest Results

\begin{tabular}{ccc}
\hline No. & Range & Category \\
\hline 1. & $12-20$ & Poor \\
2. & $21-29$ & Low \\
3. & $30-38$ & High \\
4. & $39-48$ & Very High \\
\hline
\end{tabular}

\section{RESULTS}

Universally, the term 'Badranaya' refers to the journey of a knight to find Semar's treasure. The knight represents the undergraduate guidance and counseling students who play this game. Simultaneously, the treasure in this game is a counselor with impartial character. During the journey to discover the prize, the player will find materials related to impartial character indicators. The materials are placed in the cards on the board. 
Badranaya can be played by two to four teams of three to five people. Each team should have a leader who will move the pawn with Semar shape. The teams are built to create group dynamics during the game to complete a task from the presented material on each column. The tasks become the knight journey representation, while the punishment and reward have been ruled in each task column following the material. All teams compete to obtain the Semar's treasure.

The players are prospective multicultural counselors who have to improve their impartial character. These counselors are asked to fill the impartial character scale before and after they finish their game to see their impartial character improvement. Then, their responses on the scale were analyzed using a t-test. The complete instrument format is presented in the Badranaya Guidebook. The research and data gathering, planning, as well as initial product development, resulting in a Badranaya prototype. It consists of four tools, namely the game board, game guidebook, task cards, and Semar pawn.

\section{Board Game}

This board game is one of the visual media in the form of a board with a Semar posture shape. In the game, this board is named "Semar Island." The board summarizes all local culture-based materials that are specified in the guidebook. The size of this board is $100 \mathrm{~cm} \times 100 \mathrm{~cm}$.

\section{Badranaya Game Guidebook}

The Badranaya guidebook was constructed as a reference to playing it correctly and adequately. Besides, it also aims to help the team leader comprehend the game's purpose and objectives, basic concepts, rules, steps of group counseling using it, and the ways to evaluate the game process, along with the evaluation results interpretation.

\section{Task Cards}

There are nine task cards of nine assignments adjusted to three indicators of impartial characters. Thus, each indicator is represented by three cards. The prospective multicultural councelors should complete these cards sequentially to finish this game, which is illustrated as Semar's treasure hunt.

\section{Semar Pawn}

The pawn in the shape of Semar marked the groups' journey in this board game. The group leaders deliver the summary of the Badranaya game procedures and the materials to their members, as shown in Table 3.

Table 3. Details of Procedures and Materials

\begin{tabular}{|c|c|c|c|}
\hline Meeting & Step & Duration & Activity and Material Description \\
\hline & Pre-Group & & $\begin{array}{l}\text { Preparation of the training and member selection using a } \\
\text { valid and reliable impartial character scale (pretest) }\end{array}$ \\
\hline \multirow[t]{3}{*}{ Meeting 1} & Initial Stage & 40 minutes & $\begin{array}{l}\text { The team leader explains the activity they are going } \\
\text { to do. Then, the members are asked to introduce each } \\
\text { other to create an atmosphere of comfort, cohessive, and } \\
\text { acceptance. }\end{array}$ \\
\hline & Transition Stage & 30 minutes & $\begin{array}{l}\text { The team leader asks the member to adapt to the next } \\
\text { stage. The leader also clearly explains the attitude, } \\
\text { role, and task of the leader and member so that they are } \\
\text { confident to do their task during the activities. }\end{array}$ \\
\hline & \multicolumn{3}{|c|}{ Working Stage (meeting 2-4) } \\
\hline Meeting 2 & $\begin{array}{l}\text { The implementation of } \\
\text { the Badranaya Game }\end{array}$ & 70 minutes & $\begin{array}{l}\text { The delivered materials are related to the equal } \\
\text { indicator that is summarized in tasks } 1 \text { to } 3 \text {. }\end{array}$ \\
\hline Meeting 3 & $\begin{array}{l}\text { The implementation of } \\
\text { the Badranaya Game }\end{array}$ & 70 minutes & $\begin{array}{l}\text { The delivered materials are related to the neutral } \\
\text { indicator that is summarized in task } 4 \text { to } 6 \text {. }\end{array}$ \\
\hline Meeting 4 & $\begin{array}{l}\text { The implementation of } \\
\text { the Badranaya Game }\end{array}$ & 70 minutes & $\begin{array}{l}\text { The delivered materials are related to the non- } \\
\text { stereotyping indicator that is summarized in task } 7 \text { to } 9 \text {. }\end{array}$ \\
\hline Meeting 5 & Final Stage & 70 minutes & $\begin{array}{l}\text { Conclusion and evaluation of the activity, along with the } \\
\text { impartial character scale filling by the groups' members } \\
\text { (posttest) }\end{array}$ \\
\hline
\end{tabular}


After the prototype of Badranaya was obtained, a test by experts and the small group try out were carried out as the fourth procedure (initial field try out). This stage covers a test by educational media development and guidance and counseling materials experts, along with a small group try out on six undergraduate guidance and counseling students of Universitas Nusantara PGRI Kediri. The quantitative analysis of data from guidance and counseling materials and educational media development experts shows an $86 \%$ and $83 \%$ score, respectively, categorized as very feasible. Additionally, the experts' verbal data also indicate that this media can be used as new innovative educational media, primarily in the guidance and counseling field. The details of experts' test analysis results are shown in Tables 4 and 5.

After the media had been declared feasible, a try out on six undergraduate students of the guidance and counseling program of Universitas Nusantara PGRI Kediri was carried out to discover the efficacy of Badranaya. The summary of the pretest and posttest results is presented in Table 6 .

According to the pretest and posttest scores, a transformation on the criteria is observed, from the majority of very low to high and very high. To investigate the efficacy of Badranaya, paired sample $\mathrm{t}$-test was conducted. The parametric statistical test was selected since the research data distribution was normal and homogenous. The data distribution had been tested using the Kolmogorov-Smirnov normality test, resulted in 0.995 and 0.615 for the pretest and posttest, respectively. Both scores exceed

Table 4. Results of Guidance and Counseling Expert Test

\begin{tabular}{|c|c|c|c|c|}
\hline \multicolumn{2}{|c|}{ Numerical Data } & \multicolumn{2}{|c|}{ Non-Numerical Data } & \multirow[b]{2}{*}{ Conclusion } \\
\hline Item & Score & $\begin{array}{l}\text { Suggestion from the } \\
\text { Experts }\end{array}$ & Researchers' Responds & \\
\hline 1 & 4 & \multirow{28}{*}{$\begin{array}{l}\text { In general, the materials } \\
\text { and counseling tasks have } \\
\text { followed the aspects that } \\
\text { were aimed to improve and } \\
\text { carried novelty in guidance } \\
\text { and counseling media. It } \\
\text { will be better if the product's } \\
\text { intellectual property right is } \\
\text { proposed. }\end{array}$} & \multirow{28}{*}{$\begin{array}{l}\text { No revision is required } \\
\text { on the product, but } \\
\text { following the suggestion, } \\
\text { the intellectual property } \\
\text { right for this product has } \\
\text { been proposed. }\end{array}$} & \multirow{28}{*}{$\begin{array}{l}\text { The analysis on } \\
\text { quantitative and } \\
\text { qualitative data } \\
\text { indicate that } \\
\text { materials in this } \\
\text { media is feasible to } \\
\text { be used for future } \\
\text { studies. }\end{array}$} \\
\hline 2 & 3 & & & \\
\hline 3 & 4 & & & \\
\hline 4 & 4 & & & \\
\hline 5 & 3 & & & \\
\hline 6 & 4 & & & \\
\hline 7 & 3 & & & \\
\hline 8 & 3 & & & \\
\hline 9 & 4 & & & \\
\hline 10 & 4 & & & \\
\hline 11 & 3 & & & \\
\hline 12 & 3 & & & \\
\hline 13 & 3 & & & \\
\hline 14 & 4 & & & \\
\hline 15 & 3 & & & \\
\hline 16 & 3 & & & \\
\hline 17 & 4 & & & \\
\hline 18 & 3 & & & \\
\hline 19 & 3 & & & \\
\hline 20 & 4 & & & \\
\hline 21 & 3 & & & \\
\hline 22 & 3 & & & \\
\hline 23 & 4 & & & \\
\hline 24 & 4 & & & \\
\hline 25 & 3 & & & \\
\hline Total & 86 & & & \\
\hline$\%$ & $86 \%$ & & & \\
\hline Category & $\begin{array}{l}\text { Very } \\
\text { Feasible }\end{array}$ & & & \\
\hline
\end{tabular}


the significant standard of 0.05. Meanwhile, the homogeneity test was completed using Levene Statistic, resulting in a 0.806 significance score, higher than 0.05 . These results indicate a positive difference in the subjects' impartial character level, before and after playing Badranaya. Thus, the subjects' impartial character has been improved through playing Badranaya. It is also supported by a higher average posttest score of 39 (classified as very high) than the average pretest score of 25 (categorized as very low). The detailed paired sample test is shown in Table 7.

Table 5. Results of Educational Media Development Expert Test

\begin{tabular}{|c|c|c|c|c|}
\hline \multicolumn{2}{|c|}{ Numerical Data } & \multicolumn{2}{|c|}{ Non-Numerical Data } & \multirow{2}{*}{ Conclusion } \\
\hline Item & Score & Suggestion from the Experts & Researchers' Responds & \\
\hline 1 & 3 & \multirow{6}{*}{$\begin{array}{l}\text { 1. The board material is } \\
\text { gorgeous, from Dutch } \\
\text { teak. However, it will be } \\
\text { better if the material is } \\
\text { adjusted to the school's } \\
\text { condition, to be easily } \\
\text { modified with a lighter } \\
\text { and more economical } \\
\text { material. }\end{array}$} & \multirow{23}{*}{$\begin{array}{l}\text { The Dutch teak was chosen } \\
\text { due to its durability since it } \\
\text { was expected to be used for } \\
\text { future studies with different } \\
\text { characters. However, the } \\
\text { researchers have given their } \\
\text { consent to change its necessary } \\
\text { materials to be adjusted to the } \\
\text { school's condition. } \\
\text { The terms have been reviewed } \\
\text { and revised according to the } \\
\text { subjects' psychological state. } \\
\text { The task cards' stories are } \\
\text { built following the observation } \\
\text { on subjects' condition so that } \\
\text { the discussion topics can } \\
\text { be easily reflected to form } \\
\text { new characters. Despite the } \\
\text { experts' great suggestion, the } \\
\text { researchers decided not to } \\
\text { change stories since there may } \\
\text { be a chance that the subjects } \\
\text { do not understand the wayang } \\
\text { stories. }\end{array}$} & \multirow{23}{*}{$\begin{array}{l}\text { The quantitative } \\
\text { and qualitative } \\
\text { analysis of } \\
\text { the data from } \\
\text { educational } \\
\text { media } \\
\text { development } \\
\text { experts shows } \\
\text { that the media } \\
\text { is feasible to } \\
\text { be used as an } \\
\text { innovative } \\
\text { educational } \\
\text { media in the } \\
\text { guidance and } \\
\text { counseling field. }\end{array}$} \\
\hline 2 & 3 & & & \\
\hline 3 & 4 & & & \\
\hline 4 & 3 & & & \\
\hline 5 & 4 & & & \\
\hline 6 & 3 & & & \\
\hline 7 & 3 & \multirow{17}{*}{$\begin{array}{l}\text { 2. The terms in the card } \\
\text { tasks have to be reviewed } \\
\text { and adjusted to subjects' } \\
\text { psychological conditions. } \\
\text { 3. The stories within the } \\
\text { task cards will be better } \\
\text { if replaced by the wayang } \\
\text { shadow puppet stories } \\
\text { relevant to the indicators. }\end{array}$} & & \\
\hline 8 & 3 & & & \\
\hline 9 & 4 & & & \\
\hline 10 & 3 & & & \\
\hline 11 & 3 & & & \\
\hline 12 & 3 & & & \\
\hline 13 & 3 & & & \\
\hline 14 & 4 & & & \\
\hline 15 & 3 & & & \\
\hline 16 & 3 & & & \\
\hline 17 & 4 & & & \\
\hline 18 & 3 & & & \\
\hline 19 & 4 & & & \\
\hline 20 & 3 & & & \\
\hline Total & 66 & & & \\
\hline$\%$ & $83 \%$ & & & \\
\hline Category & $\begin{array}{c}\text { Very } \\
\text { Feasible }\end{array}$ & & & \\
\hline
\end{tabular}

Table 6. Summary of Pretest and Posttest Data

\begin{tabular}{cccccc}
\hline No. & Name & \multicolumn{2}{c}{ Pretest } & \multicolumn{2}{c}{ Posttest } \\
\cline { 3 - 6 } & (Initial) & Score & Criteria & Score & Criteria \\
1 & CKM1 & 20 & Poor & 32 & High \\
2 & CKM2 & 25 & Low & 41 & Very High \\
3 & CKM3 & 29 & Low & 44 & Very High \\
4 & CKM4 & 27 & Low & 38 & High \\
5 & CKM5 & 27 & Low & 40 & Very High \\
6 & CKM6 & 24 & Low & 38 & High \\
\hline
\end{tabular}

Table 7. Results of Paired Sample Test

\begin{tabular}{lcc}
\hline & Paired Samples Test & Sig. (2-tailed) \\
\hline Pair 1 & Posttest score - pretest score & 0.000 \\
\hline
\end{tabular}




\section{DISCUSSION}

The developed Badranaya has been proven to improve the impartial character of the prospective multicultural counselors. These prospective counselors who are practically still in the undergraduate level are expected to be the practitioners who have fullfiled multicultural competencies after going to the working field. It is forecasted to reduce the field problems of guidance and counseling practice caused by the counselors. According to the fact, school counselors still stereotype their counselees. They, frequently tell the counseling results to others, and cannot resist imposing their cultural principle on their counselees. Thus, impartial character is highly required to realize healthy social living and proper and harmonious interaction between indivudual and groups (Peterson \& Seligman, 2004).

The impartial character needs to be expanded on individuals to attain success on personal-social, educational, and career aspects, as well as ensuring the behavior of the graduates in the education field (Arumsari, 2018; Borba, 2001; Setyaputri, Krisphianti, \& Puspitarini, 2018). The impartial character reinforcement on prospective multicultural counselors helps them welcome differences on other people, including their counselees. It is due to counselors' cultural background, such as their tribe and ethnicity, cannot be a measurement to be a fanatic and erase social tolerance (Mustari, 2014).

It is essential since most people do not always stay in their land of birth, including these prospective multicultural counselors who may not work in their place of birth. Therefore, they need to possess a robust, impartial character to respect and benefit others in every place they go. Consequently, a particular intervention to enhance their impartial character is required. One of the ways is by using media. A great message delivery process in guidance and counseling service is affected by the media used in the process (Alhadi, Supriyanto, \& Dina, 2016; Setyaputri, Ramli, \& Mappiare-AT, 2015). Linear to that idea, this study aims to develop a media that carries novelty, named Badranaya.

Badranaya can be integrated into Independent Learning Curriculum in the graduate guidance and counseling program, primarily in the Counselor Personal Development, Guidance and Counseling media, Guidance and Counseling Practice, and Multicultural Counseling courses. This integration relies on the point being emphasized. For instance, if used to enhance counselors' impartial character, it can be assimilated into the Counselor Personal Development course. If the emphasis is on the media development process, it can be combined in the Guidance and Counseling media development course. While if it is accentuated on the group counseling practice, the media can be used in Group Guidance and Counseling Practice course. If the emphasis is on the local culture, then it can be used in the multicultural counseling course. The integration of Badranaya in the courses and curriculum is the manifestation of new learning innovation as a transformation of individual potential as an educator. It is following an expression that the realization of a great future in the individual potential through learning innovations (Means, 2018).

Badranaya is local culture-based guidance and counseling media. The assessment from guidance and counseling and educational media development experts confirm that this media is feasible to be used as one of the innovative learning media, primarily in the guidance and counseling field. The novelty carried by this media can attract the counselees' interest to attend the guidance and counseling service. Consequently, their interest will lead them to attend the counseling consistently, from the first to the last meeting (Setyaputri, 2016; Setyaputri, 2015; Türkay, 2016). As proven in this study that the six subjects were enthusiastically joined the five meetings counseling service because of the novelty of the media. Additionally, this novelty also minimizes the mortality threat that may reduce the number of subjects during the treatment (Creswell, 2012).

This game also involves ice breaking, brainstorming, educational video, and materials written in the task cards to be discussed and role-played. The materials were formulated based on the results of observation on the subjects. Thus, it represents the events they have experienced. Therefore, they can quickly reflect and comprehend the stories' central values. During the subjects' group counseling, they energetically finished the task and shared their experiences until they got so immersed in their stories and cry, with no ability to utter words. This emotion comes from their similar backgrounds, related to their expectation, perception of people and environment, along with the social setting that aided them to interpret what has happened to them (Dewi, 2012). That social setting is originated from the manipulation of situations designed by the researchers in the Badranaya. It reveals that their stereotype, non-neutrality, and discriminative behaviors emerge from their experience (Jong \& Hodges, 2013), where they have encountered the same treatment. 
The group interaction occurs when the leader facilitates each member to support each other and construct a positive thought to build a better and more adaptive behavior. Thus, the selected symbolic models should be considered. Even if age has no significant effects on the modeling technique effectiveness, but the chosen symbolic model is better to be in the similar age to the counselees, to help them comprehend the stories better (Oliva, del Mar Aragón, \& Cuesta, 2015; Stoffers \& Van der Heijden, 2018).

The board game's and pawn's unique shape is expected to attract the counselees' interest (Clapson, Gilbert, \& Musgrove, 2020). The shapes' meaning is presented in the introduction chapter in the guidebook so that the subjects understand it before they play the game. Once they understood why the Semar figure was choosen, their positive emotions were conceived, and they started to internalize Semar's positive value. The guidebook was developed using the most operational terms to help the subjects to understand Badranaya.

Generally, the members' instruction was delivered by the teams' leader, but each member also contributed to the task accomplishment through the suggestions they made in the discussion process (Lindblom-Ylänne, Pihlajamäki, \& Kotkas, 2003). Besides, group dynamics also appeared during the discussion, with pro and contra sides. Their ability to respect each other became the initial capital to finish the game.

However, one of the lack of this study is the duration that lasts longer in each session. The maximum limit for each session is 70 minutes. The ideal group counseling duration for individuals above nine is 70 minutes (DeLucia-Waack, 2006). The more extended period was frequently caused by a long time of subjects' self-reflection session. They needed relatively longer times to disclose their thought and emotion on the discussed topic. This finding can lead to the improvement required in future studies that can be solved by the working stage. This stage initially was planned for three meetings with one indicator and three tasks for each meeting. It can be transformed into one assignment for each session.

\section{CONCLUSION}

Badranaya is one of the interactive media that can be transformed into a game. Its uniqueness is observed in its operational process that integrates local values into the phenomena frequently experience by the subjects. Its subjects are undergraduate guidance and counseling students who are expected to be professional multicultural counselors. From the development of Badranaya, the guidance and counseling program is suggested to integrate it to the Independent Learning Curriculum, primarily in the Counselor's Personal Development, Multicultural Counseling, and Guidance and Counseling courses. Besides, guidance and counseling academicians and practitioners can also use this media as a means to improve the impartial character of prospective multicultural counselors by following the rules. Additionally, they can adopt Badranaya in their future research with further dependent variables adjusted to the observation results and field condition.

\section{REFERENCES}

Absolon, K. (2010). Indigenous wholistic theory: A knowledge set for practice. First Peoples Child \& Family Review: An Interdisciplinary Journal Honouring the Voices, Perspectives, and Knowledges of First Peoples through Research, Critical Analyses, Stories, Standpoints and Media Reviews, 5(2), 74-87.

Alfadla, M. T., \& Trisnawati, P. L. (2019). Assessment of Hanoman's character value (indigenous) as a counselor competence for industrial revolution. In Social, Humanities, and Educational Studies (SHEs): Conference Series (Vol. 2, pp. 40-46).

Alhadi, S., Supriyanto, A., \& Dina, D. A. M. (2016). Media in guidance and counseling services: a tool and innovation for school counselor. SCHOULID: Indonesian Journal of School Counseling, 1(1), 6-11. https:// doi.org/10.23916/schoulid.v1i1.35.6-11

Arumsari, C. (2018). Kekuatan karakter dan kebajikan dalam bimbingan dan konseling. Journal of Innovative Counseling: Theory, Practice, and Research, 2(1), 1-5.

Borba, M. (2001). Building moral intelligence: The seven essential virtues that teach kids to do the right thing. Jossey-Bass San Francisco.

Borg, W. R., \& Gall, M. D. (1983). Educational research: An introduction. New York: Longman Publishing. 
Clapson, M. L., Gilbert, B. C. T., \& Musgrove, A. (2020). Race to the reactor and other chemistry games: Gamebased and experiential learning experiences in materials and polymer chemistry. Journal of Chemical Education, 97(12), 4391-4399. https://doi.org/10.1021/acs.jchemed.0c01135

Corey, G. (2013). Theory and practice of counseling and psychotherapy. Nelson Education.

Creswell, J. W. (2002). Educational research: Planning, conducting, and evaluating quantitative. Upper Saddle River, NJ: Prentice Hall.

DeLucia-Waack, J. L. (2006). Leading psychoeducational groups for children and adolescents. Sage Publications. Dewi, K. S. (2012). Buku ajar kesehatan mental.

Elianta, P., Prestiliano, J., \& Setiawan, T. A. (2019). Perancangan board game sebagai media pembelajaran keselamatan berkendara untuk remaja dengan mekanik dice rolling. International Journal of Natural Science and Engineering, 2(3), 80-91.

Geldard, K., \& Geldard, D. (2005). Practical counselling skills: An integrative approach. Macmillan International Higher Education.

Gleave, J., \& Cole-Hamilton, I. (2012). A world without play: A literature review. London: Play England

Jong, C., \& Hodges, T. E. (2013). The influence of elementary pre-service teachers' mathematical experiences on their attitudes towards teaching and learning mathematics'. International Electronic Journal of Mathematics Education, 8(2-3), 100-122.

Lindblom-Ylänne, S., Pihlajamäki, H., \& Kotkas, T. (2003). What makes a student group successful? Studentstudent and student-teacher interaction in a problem-based learning environment. Learning Environments Research, 6(1), 59-76. https://doi.org/10.1023/A:1022963826128

Means, A. J. (2018). Learning to save the future: Rethinking education and work in an era of digital capitalism. Routledge.

Mustari, M. (2014). Nilai Karakter refleksi untuk pendidikan. Jakarta: PT Raja Grafindo Persada.

Nursalim, M. (2013). Pengembangan media bimbingan dan konseling. Jakarta: PT Indeks.

Oliva, J. M., del Mar Aragón, M., \& Cuesta, J. (2015). The competence of modelling in learning chemical change: a study with secondary school students. International Journal of Science and Mathematics Education, 13(4), 751-791.

Peterson, C., \& Seligman, M. E. P. (2004). Character strengths and virtues: A handbook and classification. Oxford University Press.

Prameswara, A., \& Siswanto, R. A. (2016). Perancangan board game edukasi sebagai media pembelajaran untuk menumbuhkan minat baca anak jalanan di Bekasi. In eProceedings of Art \& Design (Vol. 3).

Setyanugrah, F., \& Setyadi, D. I. (2017). Perancangan board game sebagai media pembelajaran mitigasi kebakaran untuk anak sekolah dasar usia 8-12 tahun di Surabaya. Jurnal Sains dan Seni ITS, 6(1), F62-F68.

Setyaputri, N. Y. (2016). Media permainan "Roda Pelangi" sebagai alternatif pilihan media bimbingan dan konseling di sekolah. In Seminar Nasional Peran Bimbingan dan Konseling dalam Pendidikan Karakter Menyongsong Generasi Emas Indonesia. Surabaya: Universitas Negeri Surabaya.

Setyaputri, N. Y., Ramli, M., \& Mappiare-AT, A. (2015). Pengembangan media permainan "Roda Pelangi" untuk meningkatkan efikasi diri siswa SMP dalam menghadapi ujian. Bimbingan dan Konseling: Jurnal Teori dan Praktik, 28(1), 38-46.

Setyaputri, N Y. (2015). Koneksitas nilai-nilai luhur di dalam Semar (Badranaya) terhadap ciri-ciri konselor multibudaya dan praktik konseling multibudaya. In UNNES: Seminar Nasional Konseling Berbasis Multikultural (p. 92).

Setyaputri, N Y. (2017). Karakter ideal konselor multibudaya berdasarkan nilai luhur Semar. Jurnal Kajian Bimbingan dan Konseling, 2(2), 58-65. https://doi.org/http://dx.doi.org/10.17977/um001v2i22017p058

Setyaputri, N Y., Krisphianti, Y. D., \& Nawantara, R. D. (2020). Skala pengukuran karakter adil: Salah satu instrumen sebagai piranti BADRANAYA (Board-Game Karakter Konselor Multibudaya). Efektor, 7(1), 9097.

Setyaputri, N Y., Krisphianti, Y. D., \& Puspitarini, I. Y. D. (2018). Permainan Roda Pelangi sebagai media untuk meningkatkan karakter fairness siswa sekolah dasar. Jurnal Kajian Bimbingan dan Konseling, 3(3), 108-118. https://doi.org/10.17977/um001v3i32018p108

Stoffers, J. M. M., \& Van der Heijden, B. I. J. M. (2018). An innovative work behaviour-enhancing employability model moderated by age. European Journal of Training and Development, 42(1/2), 143-163.

Sudjana, N. (2011). Penilaian hasil proses belajar mengajar. PT Remaja Rosdakarya. 
Türkay, S. (2016). The effects of whiteboard animations on retention and subjective experiences when learning advanced physics topics. Computers and Education, 98, 102-114. https://oi.org/10.1016/j. compedu.2016.03.004

Yunita, I., \& Wirawan, A. R. (2017). Perancangan media board game menggunakan pendekatan edutainment untuk meningkatkan minat belajar dasar akuntansi pada sekolah menengah atas jurusan sosial. Akuntansi dan Teknologi Informasi, 11(1). https://doi.org/10.24123/jati.v11i1.326 